19 Revue d'histoire du XIXe siècle

Société d'histoire de la révolution de 1848 et des

révolutions du XIXe siècle

$26 / 27$ | 2003

Varia

Trames. $\mathrm{N}^{\circ} 10$. Revue publiée par l'IUFM de l'Académie de Rouen et le CRDP de HauteNormandie. Les frontières de l'eau.

Jean-Claude Caron

\title{
OpenEdition
}

Journals

Édition électronique

URL : https://journals.openedition.org/rh19/797

DOI : 10.4000/rh19.797

ISSN : $1777-5329$

Éditeur

La Société de 1848

Édition imprimée

Date de publication : 1 décembre 2003

Pagination : 441

ISSN : 1265-1354

Référence électronique

Jean-Claude Caron, «Trames. № 10. Revue publiée par l'IUFM de l'Académie de Rouen et le CRDP de

Haute-Normandie. Les frontières de l'eau. », Revue d'histoire du XIXe siècle [En ligne], 26/27 | 2003, mis en ligne le 23 juin 2005, consulté le 28 février 2022. URL : http://journals.openedition.org/rh19/797 ;

DOI : https://doi.org/10.4000/rh19.797

Ce document a été généré automatiquement le 28 février 2022.

Tous droits réservés 


\section{Trames. $\mathrm{N}^{\circ}$ 10. Revue publiée par l'IUFM de l'Académie de Rouen et le CRDP de Haute-Normandie. Les frontières de l'eau.}

Jean-Claude Caron

1 Au sein de cette copieuse livraison coordonnée par notre collègue rouennais JeanClaude Vimont, on relève un article d'Hélène Landre consacré à "Laurent-Antoine Pagnerre (1805-1854) : le combat pour la république d'un libraire éditeur oublié ». On sait que Pagnerre fut notamment l'éditeur du Dictionnaire politique de 1842, puis l'un des organisateurs de la campagne des banquets de 1847 et le secrétaire général du gouvernement provisoire, puis de la commission exécutive en 1848. 